\title{
The effect of hyaluronic acid on the skin healing in rats
}

\section{Efeito do ácido hialurônico na cicatrização da pele em ratos}

Lívia Medeiros Soares Celani², Isadora Soares Lopes², Aldo Cunha Medeiros ${ }^{3}$

1. Fellow Master degree, Postgraduate Program in Health Sciences, UFRN, Natal- RN, Brazil

2. Graduate student, Medical School, Federal University of Rio Grande do Norte (UFRN), Natal-RN, Brazil.

3. PhD, Full Professor, Chairman, Nucleus of Experimental Surgery, UFRN, Natal-RN, Brazil.

Research performed at the Surgery Department of the Federal University of Rio Grande do Norte (UFRN), Brazil. Scientific Initiation Program.

Financial Support: CNPq.

Conflict of interest: None.

Adress for correspondence: Surgery Department, Federal University of Rio Grande do Norte, Av. Nilo Peçanha 620, Natal, RN, Brazil. E-mail: cirurgex.ufrn@gmail.com

Submitted: september 19; accepted after revision, september 23, 2019.

\section{ABSTRACT}

Purpose: The objective of this study was to examine the effect of topical hyaluronic acid (HA) treatment on wound healing in rats. Methods: Wistar rats were randomly selected and allocated into 2 groups, with six rats each, all of them submitted to skin lesions (open wound with $5 \mathrm{~mm}$ diameter). Group 1 - rats treated with topical 0,9\% saline application in skin wounds. Group 2 - rats treated with topical hyaluronic acid $0,4 \%$ on skin wounds once a day for 7 days. After anesthesia on the 7th postoperative day, a biopsy of the skin dorsal wound area was performed for histopathological examination. A classification system based on the degree of reepithelization, granulation tissue formation and collagen organization were used to relate the morphological differences in wound healing. Results: Rats from control group treated with saline solution, on day 7, presented a general impairment of healing process, marked by an incomplete reepithelization (score $2,67 \pm 0,4$ ), a persistent exudation, fibrin, reduced accumulation of granulation tissue (score 2,2 $\pm 0,5$ ) and a slight collagen deposition (score 2,43 $\pm 0,5$ ), compared with the HA group. On the other side, morphological differences were visible on the evolution of wound repair process in rats treated with HA with a significant 
reduction in fibrinous exudation, epidermal lining reconstitution by complete reepithelization (score $3,8 \pm 0,6$ ), an increased accumulation of granulation tissue at wound edge and bed (score $3,7 \pm 1,1)$, moderate collagen deposition $(3,8 \pm 0,7)$. The respective differences between the groups were significant $(p<0,05)$. Conclusions: Based on these findings, we may conclude that HA treatment contributes to improve healing of open wounds.

Keywords: Wound healing. Hyaluronic acid. Treatment. Animal model. Rats.

\section{RESUMO}

Objetivo: O objetivo deste estudo foi examinar o efeito do tratamento tópico com ácido hialurônico (AH) na cicatrização de feridas em ratos. Métodos: Ratos Wistar foram selecionados aleatoriamente e alocados em 2 grupos, com seis ratos cada, todos submetidos a lesões cutâneas (ferida aberta com $5 \mathrm{~mm}$ de diâmetro). Grupo 1 - ratos tratados com aplicação tópica de solução salina a 0,9\% nas feridas cutâneas. Grupo 2 ratos tratados com ácido hialurônico tópico a 0,4\% nas feridas cutâneas uma vez ao dia durante 7 dias. Após anestesia no 70 dia de pós-operatório, foi realizada biópsia da área da ferida dorsal da pele para exame histopatológico. Um sistema de classificação baseado no grau de reepitelização, formação de tecido de granulação e organização do colágeno foi utilizado para relacionar as diferenças morfológicas na cicatrização de feridas. Resultados: Os ratos do grupo controle tratados com solução salina, no dia 7, apresentaram comprometimento geral do processo de cicatrização, marcado por reepitelização incompleta (escore $2,67 \pm 0,4$ ), exsudação persistente, fibrina, acúmulo reduzido de tecido de granulação $(2,2 \pm 0,5)$ e leve deposição de colágeno $(2,43 \pm 0,5)$, em comparação com o grupo $\mathrm{AH}$. Por outro lado, diferenças morfológicas eram visíveis na evolução do processo de reparo de feridas em ratos tratados com AH com redução significativa da exsudação fibrinosa, reconstituição do revestimento epidérmico por reepitelização completa (escore $3,8 \pm 0,6$ ), aumento do acúmulo de tecido de granulação na borda da ferida e no leito (escore $3,7 \pm 1,1$ ) e deposição moderada de colágeno $(3,8$ $\pm 0,7)$. As respectivas diferenças entre os grupos foram significativas $(p<0,05)$. Conclusões: Com base nesses achados, podemos concluir que o tratamento com $\mathrm{AH}$ contribui para melhorar a cicatrização de feridas abertas.

Descritores: Cicatrização de feridas. Ácido hialurônico. Tratamento. Modelo animal. Ratos. 


\section{INTRODUCTION}

Hyaluronic Acid ( $\mathrm{HA})$ is a polysaccharide that is part of the glycosaminoglycan group, basically consisting of two binded monosaccharides, D-glucuronic acid and Nacetyl-D-glucosamine. The HA usually exists in large quantity in synovial fluid, which involves joints, cartilages, eye and skin tissues. It's one of the main components of fetal cicatricial tissue extracellular matrix, which heals without any sequel or residual marks on the skin in postoperative. An experimental study was able to reduce alcohol induced fibrogenesis in vitro in normal hepatocytes ${ }^{1}$ and also induces in vitro healing of epithelial human cells using an HA formulation obtained from human umbilical cord ${ }^{2}$.

The HA has been used in animals models ${ }^{3,4}$. It was used to enhance wound recovery in models of full thickness surgical wound, and it has facilitated reepithelization, led to the formation of tissue with good elasticity and increased microvascular density ${ }^{5,6}$. It showed promising results to the repair of conjunctive tissue of tendons and cartilage in models using rabbits3. Bone repair was improved in rats and models with rabbits ${ }^{7}$. Zanchetta et al studied bone healing and observed that the best results obtained in control group might be partially explained by the transport of HA components in blood, spreading them evenly and suggesting systemic activity ${ }^{8}$. The use of chitosan-hyaluronan/fibroin in heart injuries led to the cardiac repair in rat models of myocardial infarction. Neovascularization was widely distributed in infarcted regions of myocardium in left ventricle in treatment group, being absent in control group; probably because of a higher secretion of paracrine factors in infarcted regions of the left ventricle treated with $\mathrm{HA}$, in comparison to control group ${ }^{9}$.

A relevant information is the fact that wounds after fetal surgery have perfect healing, without marks. Fetal wounds are unique in their capability of rapidly healing without residual scars. The amniotic fluid, rich in nutrients, growth factors and hyaluronic acid, involves the fetus and is essential to fetal wounds healing. The healing properties of fetal lesions may be the result of high concentrations of hyaluronic acid ${ }^{10}$.

Considering the data explained above, we hypothesized that topical treatment of skin lesions with hyaluronic acid may positively influence the healing of skin in rats. 


\section{METHODS}

Wistar rats weighing $286 \pm 31 \mathrm{~g}$ were used. This protocol was submitted and approved by the institutional Comission of Ethics on the use of Animals, under protocol 2018/7. The Wistar rats were maintained in individual polypropylene cages with 12 -hour light-dark cycles. Initially, the animals went trough a 7-days period of acclimatization at the Nucleus of Experimental Surgery-UFRN, with access ad libitum to water and rat food (Presence ${ }^{\circledR}$ ). The care taken in the use of those animals followed the guidelines of Brazilian Legislation for the scientific use of animals (Low no 11.794/2008).

The animals were randomly selected and allocated into two groups, with six rats each, all of them submitted to skin lesions (open wound with $5 \mathrm{~mm}$ diameter):

Group 1 - rats treated with topical 0,9\% saline application in skin wounds.

Group 2 - rats treated with topical hyaluronic acid 0,4\% (Adaptis, Legrand, Brasil) on skin wounds once a day for 7 days.

\section{Surgical procedures}

For performing surgical procedures, the rats were anesthetized with intraperitoneal (I.P.) ketamine $70 \mathrm{mg} / \mathrm{Kg}$ weight, associated with xylazine at $7 \mathrm{mg} / \mathrm{Kg}$ weight and they were operated under aseptic technique.

The animals were fixed to the operating table in prone position, epilated the skin from the back and antisepsis with $70 \%$ ethyl alcohol was made. A $5 \mathrm{~mm}$ diameter skin segment was resected from the dorsal with the aid of an aortic Punch (EDLO, Canoas, RS, Brasil), leaving an open wound to heal by second intention. Postoperative pain was controlled with analgesia (Meperidine, I.M., at $10 \mathrm{mg} / \mathrm{Kg}$, once a day for the first 3 days). The animals were observed in their individual cages and they received solid diet for rats and water ad libitum until the 7th day of observation. The rats were weighed before surgery and a few moments before euthanasia (with an intraperitoneal thiopental injection at $100 \mathrm{mg} / \mathrm{kg})$..

\section{Skin healing Assessment}

To histologically evaluate the effects of different treatment modalities on the healing process, the samples were surgically removed from the wounds at the time of the euthanasia and routinely processed. The excised tissues were fixed in $10 \%$ buffered 
formalin, dehydrated in alcohol, washed in xylene and embedded in paraffin. Five micrometers $(5 \mu \mathrm{m})$ sections of tissue, including epidermis, dermis and subcutaneous panniculus carnosus were cut and stained with hematoxylin and eosin. The samples were evaluated in optical microscope (Olympus BX51). A classification system based on the degree of reepithelization, granulation tissue formation and collagen organization were used to relate the morphological differences in wound healing, as described in Table 1. Scores were given according to the system previously reported to assess wound repair maturity11.

Table 1. Morphological scores

\begin{tabular}{llll}
\hline Score & Re-epithelialization & Granulation tissue formation & $\begin{array}{c}\text { Collagen } \\
\text { organization }\end{array}$ \\
\hline $\mathbf{0}$ & None & None & None \\
$\mathbf{1}$ & Migrating & Hypo cellular with few vessels & Trace \\
$\mathbf{2}$ & Partial stratum corneum & Many vessels and some cells & Slight \\
$\mathbf{3}$ & Hypertrophic & Many fibroblasts, some fibers & Moderate \\
$\mathbf{4}$ & Complete and normal & More fibers, few cells & Marked \\
\hline
\end{tabular}

\section{Statistic}

Statistical evaluation was made by BioEstat 5.0 software (Belém, PA, Brasil) using Student's t test, and statistical significance were considered when $p<0,05$.

\section{RESULTS}

Using a histological score system, rats from control group treated with saline solution, on day 7 , presented a general impairment of healing process, marked by an incomplete reepithelization (score $2,67 \pm 0,4$ ), a persistent exudation, fibrin, reduced accumulation of granulation tissue (score 2,2 $\pm 0,5$ ) and a slight collagen deposition (score $2,43 \pm 0,5$ ), compared with the HA group. On the other side, morphological differences were visible on the evolution of wound repair process in rats treated with HA with a significant reduction in fibrinous exudation, epidermal lining reconstitution by complete reepithelization (score 3,8 $\pm 0,6$ ), an increased accumulation of granulation tissue at wound edge and bed (score $3,7 \pm 1,1)$, moderate collagen deposition $(3,8 \pm 0,7)$. The respective differences between the groups were significant $(p<0,05)$. These data are summarized in Table 2. 
Table 2. Summary of impact of two treatments (saline and hyaluronic acid) on histopathological scores of skin wound healing in rats (mean \pm standard deviation).

\begin{tabular}{cccc}
\hline Rat models & Epithelization & Granulation tissue & $\begin{array}{c}\text { Collagen } \\
\text { organization }\end{array}$ \\
\hline $\begin{array}{c}\text { Control group } \\
\text { (saline) }\end{array}$ & $2,67 \pm 0,4$ & $2,2 \pm 0,5$ & $2,43 \pm 0,5$ \\
$\begin{array}{c}\text { Hyaluronic Acid } \\
\text { group }\end{array}$ & $3,8 \pm 0,6^{*}$ & $3,7 \pm 1,1^{*}$ & $3,8 \pm 0,7^{*}$ \\
\hline Student's t test, ${ }^{*} \mathrm{p}<0,05$ when compared with control group. & \\
\hline
\end{tabular}

The rats in control group showed evidence of continuous epithelial lining, hypocellular zones with few vessels in granulation tissue and a slight deposition of collagen fibers (Fig. 1A, B). Among samples collected in rats from hyaluronic acid group, skin showed a hypertrophic epithelial lining, indicating that a new epidermis was completely formed. A large zone of granulation tissue formed at the wound edge and bed, with numerous fibroblasts and an accentuated deposition of collagen fibers were observed (Fig. 1C, D). 

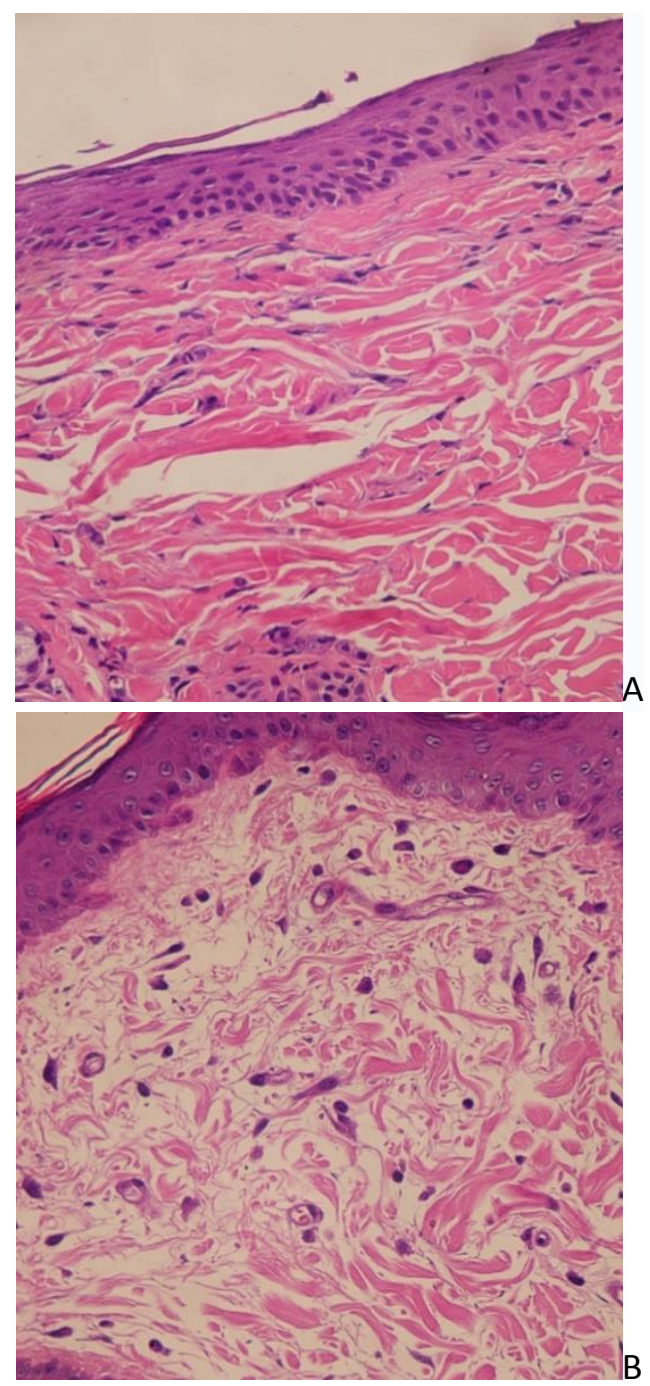

Control group $(\mathrm{A}, \mathrm{B})$
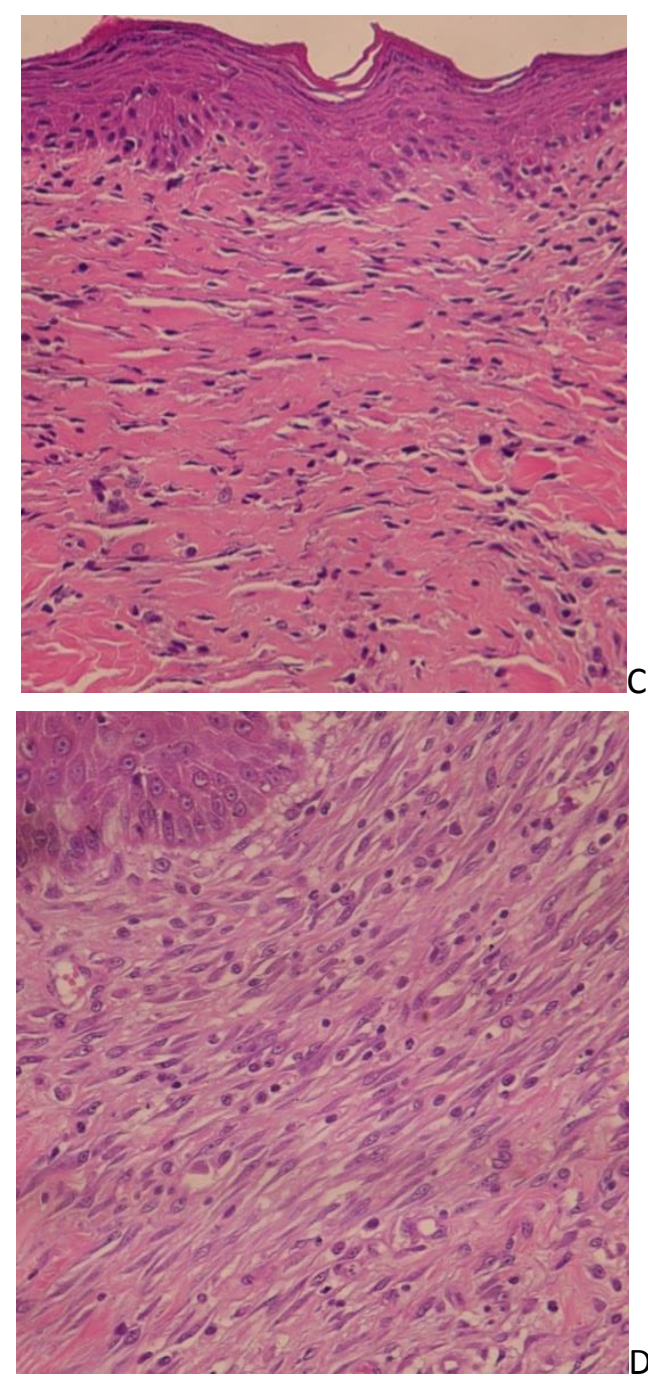

Hyaluronic acid group (C,D)

Figure 1. Control group: evidence of a continuous epithelial lining, a Hypo cellular zone with few vessels in granulation tissue; a moderate deposition of collagen fibers (HE, 100X). Hyaluronic acid group: presence of continuous hypertrophic epidermis with neodermis showing a high degree of granulation tissue, many fibroblasts and marked collagen deposition (HE 100X).

\section{DISCUSSION}

To evaluate the efficacy of HA as a wound treatment, a rat model with fullthickness wounds was used and compared with non-treated wounds. Morphological analysis demonstrated that HA significantly accelerated wound repair through reepithelization and proliferation of granulation tissue, fibroblasts and collagen. Histologically, wounds treated with HA presented thicker regenerated skin, increased total quantity of blood vessels, specifically small and newly formed vessels. The observations in vivo that HA was beneficial for fibroblasts and collagen proliferation 
were supported by the histological analysis, in which a higher number of proliferating cells were seen in wounds treated with HA. Those findings that HA support fibroblast proliferation in vivo may be explained by this proteoglycan in extracellular matrix.

The rat injury and wound regeneration model is commonly used for basic research studies and evaluation of possible new therapies. Nevertheless, there are significant limitations to these models that are well recognized. First, unlike humans, in which is very unlikely that huge acute wounds heal without intervention, rats have a remarkable endogenous regeneration potential. However, the seven-day healing process observed in this study offers the opportunity to compare the influence of wound treatments based on the speed of epithelization, collagen formation and granulation tissue. Although it was found significant improvement in these parameters in rat and mice models, it is estimated that theses advances would have a even higher impact in wound healing. Some studies confirm these affirmations ${ }^{12-15}$.

A hydrogel composed of HA promoted dermis regeneration and wound healing. Dermal and epidermal cell fractions were positively affected on healing, meliorated by the hydrogel16. In a previous work, a topical hydrogel with HA provided an adhesion barrier in a rat model after midline abdominal incision and facilitated healing ${ }^{17}$. An HAbased spongy leaf incorporated with epidermal growth factor helped wound healing in rat models when integrated to the peritoneum ${ }^{18}$. The use of HA impregnated autologous skin graft in patients submitted to surgical removal of scars facilitated a better graft integration into the surrounding tissues, with dermis regeneration ${ }^{19}$.

Hyaluronic acid plays several roles in healing. Although inflammation is crucial to granulation tissue formation, stabilization of this tissue matrix is necessary, relieving inflammation to maintain normal tissue repair. The role of free radical scavenging by HA may influence inflammatory activation. In this sense, HA provides protection against free radicals and proteolytic damage to cells and to extracellular matrix ${ }^{20}$.

Campo et $\mathrm{al}^{21}$ showed that $\mathrm{HA}$ reduces inflammatory mediators as tumor necrosis factor- $\alpha$, IL-1 $\beta$, IL-17, MMP-13 and nitric oxide synthetase, which play active roles in inflammation and cartilage destruction in an experimental model of mice with arthritis. The HA is one of the main components of extracellular matrix, and is the most important structure of proteoglycans. It is also associated with fibronectin, collagen, 
fibrin and other molecules of the matrix. HA promotes early response to tissue damage and transient fibrin-rich matrix formation. Accordingly, it promotes fibroblasts and endothelial cells movement to wound area and subsequent granulation tissue formation in the early phase of tissue repair ${ }^{20,21}$.

The fact that it was observed an accelerated closure of the wounds in our study, driven mainly by increased epithelization and collagen production, suggests that HA can be applies to full-thickness wounds to promote healthy regenerated skin formation, as observed in this study. Specifically, improvements in fibroblast proliferation in HA group compared with control group was seen. In the same way, wounds treated with HA had a thicker regenerated tissue and slightly higher levels of epithelial cell formation as compared with untreated wounds. Based on these findings, we may conclude that HA treatment contributes to improve healing of open wounds. Further studies could test the effectiveness of HA in animal models of wound healing with bigger wounds, or even in wounds of diabetic animals, as well as explore its use in the clinical setting.

\section{REFERENCES}

1. Neuman MG, Nanau RM, Oruña L, Coto G. In vitro anti-inflammatory effects of hyaluronic acid in ethanol-induced damage in skin cells. J Pharm Pharm Sci. 2011; 14:425-37.

2. Neuman MG, Oruña L, Coto G, Lago G, Nanau R, Vincent M. Hyaluronic acid signals for repair in ethanol-induced apoptosis in skin cells in vitro. Clin Biochem. 2010; 43:822-6.

3. Oryan A, Moshiri A, Meimandi Parizi AH, Raayat Jahromi A. Repeated administration of exogenous Sodium-hyaluronate improved tendon healing in an in vivo transection model. J Tissue Viability. 2012; 21:88-102.

4. Tuncay I, Erkocak OF, Acar MA, Toy $\mathrm{H}$. The effect of hyaluronan combined with microfracture on the treatment of chondral defects: an experimental study in a rabbit model. Eur J Orthop Surg Traumatol. 2013; 23:753-8.

5. Zhao JY, Chai JK, Song HF, Zhang J, Xu MH, Liang YD. Influence of hyaluronic acid on wound healing using composite porcine acellular dermal matrix grafts and autologous skin in rabbits. Int Wound J. 2013; 10:562-72.

6. Shimizu N, Ishida D, Yamamoto A, Kuroyanagi M, Kuroyanagi Y. Development of a functional wound dressing composed of hyaluronic acid spongy sheet containing bioactive components: evaluation of wound healing potential in animal tests. J Biomater Sci Polym Ed. 2014; 25:1278-91. 
7. Chen $Q$, Sun $G$, Wang $Y$, Zhong $W$, Shu XZ. The evaluation of two new hyaluronan hydrogels as nasal dressing in the rabbit maxillary sinus. Am J Rhinol Allergy, 2012; 26:152-6.

8. Zanchetta P, Lagarde N, Uguen A, Marcorelles P. Mixture of hyaluronic acid, chondroitin 6 sulphate and dermatan sulphate used to completely regenerate bone in rat critical size defect model. J Craniomaxillofac Surg, 2012; 40:783-7.

9. Chi NH, Yang MC, Chung TW, Chou NK, Wang SS. Cardiac repair using chitosanhyaluronan/silk fibroin patches in a rat heart model with myocardial infarction. Carbohydr Polym, 2013; 92:591-7.

10. Nyman E, Huss F, Nyman T, Junker J, Kratz G. Hyaluronic acid, an important factor in the wound healing properties of amniotic fluid: in vitro studies of reepithelialisation in human skin wounds. J Plast Surg Hand Surg. 2013;47(2):89-92.

11. Hebda PA, Whaley D, Kim HG, Wells A. Absence of inhibition of cutaneous wound healing in mice by oral doxycycline. Wound Rep Reg. 2003;11:373-9.

12. Wang HM, Chou YT, Wen ZH, Wang CZ, Chen CH, Ho ML. Novel biodegradable porous scaffold applied to skin regeneration. PLoS One. 2013; 8:e56330.

13. Cerqueira MT, da Silva LP, Santos TC, Pirraco RP, Correlo VM, Marques AP, Reis RL. Human skin cell fractions fail to self-organize within a gellan gum/hyaluronic acid matrix but positively influence early wound healing. Tissue Eng Part A. 2014; 20:1369-78.

14. de Brito Bezerra B, Mendes Brazão MA, de Campos ML, Casati MZ, Sallum EA, Sallum AW. Association of hyaluronic acid with a collagen scaffold may improve bone healing in critical-size bone defects. Clin Oral Implants Res. 2012; 23:938-42.

15. Bae MS, Ohe JY, Lee JB, Heo DN, Byun W, Bae H, Kwon YD, Kwon IK. Photo-cured hyaluronic acid-based hydrogels containing growth and differentiation factor 5 (GDF-5) for bone tissue regeneration. Bone. 2014; 59:189-98.

16. Yan S, Zhang Q, Wang J, Liu Y, Lu S, Li M, Kaplan DL. Silk fibroin/chondroitin sulfate/hyaluronic acid ternary scaffolds for dermal tissue reconstruction. Acta Biomater. 2013; 9:6771-82.

17. $\mathrm{Na} \mathrm{SY}$, Oh SH, Song $\mathrm{KS}$, Lee JH. Hyaluronic acid/mildly crosslinked alginate hydrogel as an injectable tissue adhesion barrier. J Mater Sci Mater Med. 2012; 23:2303-13.

18. Kuroyanagi M, Yamamoto A, Shimizu N, Toi A, Inomata T, Takeda A, Kuroyanagi $Y$. Development of anti-adhesive spongy sheet composed of hyaluronic acid and collagen containing epidermal growth factor. J Biomater Sci Polym Ed. 2014; 25:1253-65.

19. Faga A, Nicoletti G, Brenta F, Scevola S, Abatangelo G, Brun P. Hyaluronic acid three-dimensional scaffold for surgical revision of retracting scars: a human experimental study. Int Wound J. 2013; 10:329-35.

20. Foschi D, Castoldi L, Radaelli E, Abelli P, Calderini G, Rastrelli A, Mariscotti C, Marazzi $M$, Trabucchi E. Hyaluronic acid prevents oxygen free-radical damage to granulation tissue: a study in rats. Int J Tissue React. 1990;6:333-9. 
21. Campo GM1, Avenoso A, Nastasi G, Micali A, Prestipino V, Vaccaro M, D’Ascola A, Calatroni A, Campo S. Hyaluronan reduces inflammation in experimental arthritis by modulating TLR- 2 and TLR-4 cartilage expression. Biochim Biophys Acta. 2011;9:1170-81. 